\title{
WYBRANE INICJATYWY Z ZAKRESU WSPIERANIA EDUKACJI I ICH WPLYW NA ROZWÓJ SPOLECZNO-EKONOMICZNY OBSZARÓW WIEJSKICH POMORZA
}

\begin{abstract}
Zarys treści: W niniejszym artykule, na przykładzie Pomorza (województwa pomorskiego i zachodniopomorskiego), zaprezentowano wybrane działania edukacyjne podejmowane przez społeczności lokalne, które wpływają na rozwój społeczno-ekonomiczny pomorskich wsi. Zobrazowano ogólny stan szkolnictwa obszaru badawczego. Uwzględniono aktywność wybranych organizacji w zakresie edukacji dzieci i młodzieży pochodzącej ze środowisk wiejskich, głównie poprzez tworzenie małych szkół i przedszkoli, a także specjalizacji wsi. Ponadto, zwrócono uwagę na kwestię wykorzystania środków unijnych w tym zakresie.
\end{abstract}

Słowa kluczowe: obszary wiejskie, edukacja, społeczność lokalna.

\section{Wprowadzenie}

Proces rozwoju obszarów wiejskich jest wypadkową wielu czynników, w szczególności związanych z ludnością, przedsiębiorczością i atrakcyjnością inwestycyjną, zasobami naturalnymi i środowiskiem, rolnictwem i gospodarką żywnościową, szansami edukacyjnymi, jakością i dostępnością usług publicznych, dostępnością centrów rozwoju i głównych szlaków komunikacyjnych oraz dostępnością informacji i technik nowoczesnego komunikowania się (Kierunki rozwoju... 2010).

Jednym z ważniejszych elementów wpływających na rozwój społeczno-ekonomiczny wsi jest edukacja. W potocznym znaczeniu rozumiana jako synonim szkolnictwa - systemu wyspecjalizowanych instytucji, których zadaniem jest transmisja wiedzy, kompetencji i umiejętności (Wnuk-Lipiński, Ziółkowski 2001). Edukacja według W. Okonia (2007) jest to ogół procesów i oddziaływań, których celem jest zmienianie ludzi, przede wszystkim dzieci i młodzieży, stosownie do panujących w danym społeczeństwie ideałów i celów wychowawczych. Zgodnie z reformą edukacji, która definiuje pojęcie bardziej szczegółowo, jest to 
realizacja programu ewolucji istoty ludzkiej $\mathrm{w}$ toku całego życia $\mathrm{z}$ myślą o integralnym rozwoju w zakresie umysłowym, fizycznym, afektywnym, moralnym, duchowym; proces obejmujący nie tylko przekazywanie wiedzy i umiejętności, szeroko pojętych wartości kultury, lecz także inspirowanie postawy twórczej, otwartej, samodzielności myślenia, zdolności do samokształcenia. To także sprzyjanie integracji jednostek z życiem kulturalnym, społecznym, ekonomicznym określonej wspólnoty, a tym samym przygotowanie rezerw ludzkich dla jej wzbogacania (Adamczyk, Dutkiewicz 2000).

Powołując się na zalecenia Międzynarodowej Komisji ds. Edukacji XXI wie$\mathrm{ku}$, edukację każdego człowieka, bez względu na jego miejsce zamieszkania, powinny ukierunkować cztery cele:

1. Uczyć się, aby wiedzieć - aby zdobywać narzędzia rozumienia świata otaczającego, aby godnie żyć, rozwijać swoje zdolności i umiejętności...,

2. Uczyć się, aby działać - aby móc oddziaływać na swoje środowisko, aby stosować zdobytą wiedzę i ukształtowane umiejętności...,

3. Uczyć się, aby żyć wspólnie - aby uczestniczyć i współpracować z innymi na wszystkich płaszczyznach działalności ludzkiej...,

4. Uczyć się, aby być - aby nie poddać się dehumanizacji świata w związku z ewolucją techniczną, aby być zdolnym kształtować samodzielne i krytyczne myślenie oraz wypracować niezależność sądów, aby samemu decydować o słuszności podejmowanych działań w różnych okolicznościach życia (Delors 1998). Zdaniem B. Siemienieckiej (2003) w procesie edukacji nie tylko uczymy się myśleć i zdobywamy wiedzę, ale również przejmujemy postawy życiowe i sposób odbierania rzeczywistości. Edukacja jest zatem ważnym ogniwem ogólnego rozwoju oraz fundamentem postępowania i działania w większości obszarów ludzkiej aktywności.

Zakres przestrzenny prowadzonych badań obejmuje województwa: pomorskie i zachodniopomorskie, zajmujące łączną powierzchnię $41202,82 \mathrm{~km}^{2}$, co stanowi $13,1 \%$ powierzchni kraju. Zasadniczym celem niniejszego opracowania jest prezentacja wybranych inicjatyw edukacyjnych podejmowanych przez społeczności lokalne, a także wykazanie ich wpływu na rozwój społeczno-ekonomiczny obszarów wiejskich Pomorza.

\section{Stan szkolnictwa na obszarach wiejskich Pomorza}

Z danych Głównego Urzędu Statystycznego (GUS) wynika, iż w roku szkolnym 2012/2013 na obszarach wiejskich Pomorza do różnych typów szkół uczęszczało ogółem 136856 uczniów, w tym 91286 w województwie pomorskim i 45570 w województwie zachodniopomorskim. O ile na wsi nadal dominuje wykształcenie podstawowe i gimnazjalne, o tyle $\mathrm{w}$ miastach średnie. Zdecydowaną większość stanowili uczniowie szkół podstawowych i gimnazjów. Spośród uczniów szkół podstawowych w województwie pomorskim do szkół wiejskich 
uczęszczało $38,1 \%$, a w zachodniopomorskim - 26,9\%. Zdecydowanie wyższy był udział młodzieży wiejskiej w gimnazjach. W przypadku województwa pomorskiego 43,6\% uczęszczało do gimnazjów na wsiach, a zachodniopomorskiego - 38,5\%. Znacznie gorzej przedstawiała się kwestia dostępności do szkół ponadgimnazjalnych na obszarach wiejskich Pomorza (tab. 1). Zlokalizowanych jest tam niewiele tego typu szkół, stąd udział uczniów uczęszczających do placówek jest zdecydowanie wyższy w miastach. W przypadku województwa pomorskiego zaledwie 10,3\% liceów, techników i zasadniczych szkół zawodowych zlokalizowanych jest na wsiach, a uczy się w nich $6,5 \%$ młodzieży. Udział jest jeszcze niższy w województwie zachodniopomorskim i wynosi odpowiednio $3,4 \%$ i $1,1 \%$.

Tabela 1

Uczniowie pomorskich szkół wiejskich w 2013 roku

\begin{tabular}{|c|c|c|c|c|c|c|}
\hline \multirow{3}{*}{$\begin{array}{l}\text { Placówka } \\
\text { edukacyjna }\end{array}$} & \multicolumn{2}{|c|}{$\begin{array}{l}\text { Województwo } \\
\text { pomorskie }\end{array}$} & \multicolumn{2}{|c|}{$\begin{array}{c}\text { Województwo } \\
\text { zachodniopomorskie }\end{array}$} & \multicolumn{2}{|c|}{ Pomorze } \\
\hline & \multicolumn{6}{|c|}{ Liczba uczniów } \\
\hline & ogółem & wieś & ogółem & wieś & ogółem & wieś \\
\hline $\begin{array}{l}\text { Szkoła } \\
\text { Podstawowa }\end{array}$ & 139530 & 53228 & 92829 & 25022 & 232359 & 78250 \\
\hline Gimnazjum & 72972 & 31831 & 51420 & 19805 & 124392 & 51636 \\
\hline $\begin{array}{l}\text { Zasadnicza } \\
\text { Szkoła Zawodowa }\end{array}$ & 14619 & 1513 & 8926 & 210 & 23545 & 1723 \\
\hline $\begin{array}{l}\text { Liceum } \\
\text { Ogólnokształcące } \\
\text { i uzupełniające }\end{array}$ & 48229 & 1388 & 36680 & 11 & 84909 & 1399 \\
\hline $\begin{array}{l}\text { Liceum } \\
\text { profilowane }\end{array}$ & 385 & 41 & 198 & 0 & 583 & 41 \\
\hline $\begin{array}{l}\text { Technikum } \\
\text { i technikum } \\
\text { uzupełniające }\end{array}$ & 31886 & 3285 & 22000 & 522 & 53886 & 3807 \\
\hline Razem & 307621 & 91286 & 212053 & 45570 & 519674 & 136856 \\
\hline
\end{tabular}

Źródło: opracowanie własne na podstawie Oświata $i$ wychowanie $w$ roku szkolnym 2012/2013, 2013, GUS, Warszawa.

Poziom szkolnictwa jest podstawą rozwoju kapitału ludzkiego. W ostatnich latach, ze względu na zmiany zachodzące w strukturze demograficznej ludności, których przejawem jest malejąca liczba dzieci i młodzieży, ograniczonym staje się także nabór do szkół. Zmniejsza się liczba ludności na peryferyjnych obszarach wiejskich, przy jednoczesnym przyroście liczby ludności wokół największych miast i dowożeniu części dzieci do szkół miejskich. Wynikiem 
tych procesów jest zmniejszająca się liczba placówek szkolnych, a tym samym malejąca dostępność szkół. J. Wilkin (2003) podzielił bariery dostępu do edukacji na wsi na trzy grupy - ekonomiczne, przestrzenno-lokalizacyjne oraz środowiskowo-kulturalne.

Na gorszy start i mniejsze szanse edukacyjne dzieci z obszarów wiejskich wpływa szereg barier związanych z funkcjonowaniem systemu oświatowego na wsi (np. ograniczenie dostępu do poradnictwa wspomagającego rozwój zdrowotny i edukacyjny najmłodszych dzieci, ograniczenie dostępu do przedszkoli, ograniczenie dostępu do Internetu, większe niż w miastach zróżnicowanie poziomu kwalifikacji nauczycieli, gorsza oferta edukacyjna szkolnictwa ponadgimnazjalnego, mniejsze możliwości kształcenia ustawicznego dorosłych), a także konieczność zaspokajania specyficznych potrzeb występujących w tym środowisku (np. w okresie intensywnych prac polowych), pokonywania barier związanych z sytuacją materialną rodzin wiejskich oraz ich aspiracjami edukacyjnymi. Również infrastruktura edukacyjna, społeczna, teleinformatyczna i kulturalna na obszarach wiejskich jest niedoinwestowana oraz niedostosowana do lokalnych potrzeb (Program rozwoju edukacji... 2008). Jednak na obszarach wiejskich Pomorza podejmowane są różnorodne działania, mające na celu zapobieganie likwidacji małych szkół i przedszkoli, a także tworzenie nowych placówek edukacyjnych, na co Autorka zwraca uwagę w dalszej części artykułu.

Obszary wiejskie Pomorza nierozerwalnie związane są z rolnictwem, pomimo iż w ostatnich latach jego rola znacznie zmalała. W wielu gminach nadal jest dominującą funkcją gospodarczą (Czapiewska 2014). Uzasadniona jest zatem potrzeba dostępności do szkół rolniczych w regionie. Obecnie w skali kraju funkcjonuje 45 zespołów szkół rolniczych prowadzonych przez Ministra Rolnictwa i Rozwoju Wsi oraz 414 placówek prowadzonych przez jednostki samorządu terytorialnego ${ }^{1}$. Na Pomorzu funkcjonują zaledwie dwa Zespoły Szkół Centrum Kształcenia Rolniczego - w Boninie i Mieszkowicach (województwo zachodniopomorskie) nadzorowane przez MRiRW. Warto wspomnieć, iż w tym przypadku województwo pomorskie pozostaje jedynym w Polsce, na terenie którego nie funkcjonuje żaden ministerialny zespół szkół rolniczych. Natomiast w pomorskim zlokalizowanych jest 50 szkół rolniczych $(12,0 \%$ ogółu szkół rolniczych) prowadzonych przez jednostki samorządu terytorialnego. Na terenie zachodniopomorskiego funkcjonuje ich 7 (1,7\%).

Pierwszym etapem edukacji dzieci jest wychowanie przedszkolne. Na Pomorzu funkcjonuje ogółem 2044 przedszkoli, z czego 936 (45,8\%) na obszarach wiejskich. Edukację przedszkolną realizują przedszkola, zespoły i punkty przedszkolne, a także oddziały przedszkolne przy szkołach podstawowych. Udział tych ostatnich, zarówno w skali kraju, jak i Pomorza jest zdecydowanie największy (tab. 2). W województwie pomorskim stanowią one 57,7\% ogólnej liczby placówek przedszkolnych, a zachodniopomorskim - 62,9\%. Uczęszcza do

\footnotetext{
${ }^{1}$ Wykaz szkół rolniczych w Polsce.
} 
nich 47,5\% dzieci (16 218 osób). Ogółem w wiejskich placówkach przedszkolnych na Pomorzu opiekę i edukację pobiera 34093 dzieci, w tym z obszarów województwa pomorskiego 23983 osób (70,3\%), a zachodniopomorskiego 10110 osób (29,7\%). Występuje jednak pewne zróżnicowanie w liczebności dzieci uczęszczających do poszczególnych placówek. W województwie pomorskim większość $\mathrm{z}$ nich otrzymuje opiekę w przedszkolach $(49,1 \%)$, zaś W zachodniopomorskim ponad połowa dzieci wiejskich $(54,3 \%) \mathrm{w}$ oddziałach przedszkolnych funkcjonujących w szkołach podstawowych. Warto zwrócić uwagę na fakt, iż pomimo coraz korzystniejszej sytuacji z dostępem dzieci wiejskich do przedszkoli, to nadal widoczne są znaczne dysproporcje w tym względzie pomiędzy miastem a wsią. Spośród ogólnej liczby dzieci uczęszczających do przedszkoli $\mathrm{w}$ województwie pomorskim, blisko $1 / 3$ stanowią wychowankowie przedszkoli wiejskich $(32,3 \%)$. Z kolei w województwie zachodniopomorskim jedynie $1 / 5$, tj. 19,9\% ogólnej liczby dzieci, uczęszcza do przedszkoli zlokalizowanych na wsiach. Średnio na jedno przedszkole przypada w pomorskim 40,8 dzieci, zaś w zachodniopomorskim - 29. Z kolei na jedno miejsce w wiejskiej placówce wychowania przedszkolnego przypada odpowiednio 2,24 i 3,21 dzieci. Na badanym terenie zróżnicowany jest także udział dzieci korzystających z przedszkoli w stosunku do ogółu dzieci w wieku przedszkolnym (3-6 lat). W województwie pomorskim był on zdecydowanie wyższy i wynosił 56,4\%, zaś w zachodniopomorskim - 42,4\%.

Tabela 2

Wiejskie placówki przedszkolne Pomorza na tle kraju

\begin{tabular}{|l|r|r|r|r|r|r|r|}
\hline \multirow{2}{*}{ Rodzaj placówki } & \multicolumn{2}{|c|}{ Polska } & \multicolumn{2}{c|}{$\begin{array}{c}\text { Województwo } \\
\text { pomorskie }\end{array}$} & \multicolumn{2}{c|}{$\begin{array}{c}\text { Województwo } \\
\text { zachodniopomorskie }\end{array}$} \\
\cline { 3 - 9 } & & \multicolumn{1}{|c|}{ liczba } & \multicolumn{1}{c}{$\%$} & liczba & \multicolumn{1}{c|}{$\%$} & liczba & $\%$ \\
\hline Przedszkola & a & 3213 & 29,3 & 179 & 30,4 & 61 & 17,5 \\
& $\mathrm{~b}$ & 204573 & 52,2 & 11798 & 49,1 & 3408 & 33,7 \\
\hline Zespoły & $\mathrm{a}$ & 88 & 0,8 & 2 & 0,3 & - & - \\
wychowania & $\mathrm{b}$ & 1371 & 0,4 & 26 & 0,1 & - & - \\
przedszkolnego & & & & & & & \\
\hline Punkty & $\mathrm{a}$ & 997 & 9,1 & 68 & 11,6 & 68 & 19,6 \\
przedszkolne & $\mathrm{b}$ & 18818 & 4,8 & 1427 & 6,0 & 1216 & 12,0 \\
\hline Oddziały & $\mathrm{a}$ & 6656 & 60,8 & 339 & 57,7 & 219 & 62,9 \\
przedszkolne & $\mathrm{b}$ & 166907 & 42,6 & 10732 & 44,8 & 5486 & 54,3 \\
\hline Ogółem & $\mathrm{a}$ & 10954 & 100,0 & 588 & 100,0 & 348 & 100,0 \\
& $\mathrm{~b}$ & 391669 & 100,0 & 23983 & 100,0 & 10110 & 100,0 \\
\hline
\end{tabular}

Objaśnienia: a - liczba placówek, b - liczba dzieci.

Źródło: opracowanie własne na podstawie Oświata $i$ wychowanie $w$ roku szkolnym 2012/2013, 2013, GUS, Warszawa. 


\section{Aktywizacja środowisk lokalnych na rzecz rozwoju edukacji}

W aktualnej rzeczywistości niemal tak samo ważna jak edukacja, którą dzieci odbierają w szkole, stała się edukacja przedszkolna. W znacznej mierze wpływa ona na indywidualny rozwój każdego dziecka. Większość wrodzonych umiejętności rozwija się intensywnie w wieku przedszkolnym, dotyczy to także zdolności uczenia się. Dlatego działania edukacyjne, pobudzanie rozwoju intelektualnego i społecznego dziecka, przynoszą najlepsze efekty właśnie w tym czasie. Dowodzą tego również wyniki, trwających ponad 30 lat, badań prowadzonych w ramach amerykańskiego programu „Perry pre-school Project”. Dzieci, które chodziły do przedszkoli: zdobywają wyższe wykształcenie, mają lepszą pracę i więcej zarabiają, osiągają wyższy standard życia, rzadziej naruszają prawo i bywają karane, rzadziej korzystają z pomocy społecznej niż osoby o podobnych możliwościach intelektualnych i społecznych, które nie uczęszczały w dzieciństwie na zajęcia przedszkolne.

$\mathrm{Na}$ wsi przedszkole nie tylko edukuje, ale także rozwija kompetencje społeczne, wyrównuje szanse edukacyjne, wspiera indywidualne potrzeby edukacyjne dzieci, a przy tym stanowi wsparcie dla rodziców.

Generalnie dzieci wiejskie mają znacznie trudniejszy dostęp do edukacji przedszkolnej aniżeli dzieci $\mathrm{w}$ miastach. Jednak w ostatnich latach podejmowane są pewne działania mające na celu zniwelowanie istniejących dysproporcji. Przykładem jest realizacja projektu „Małe Przedszkole w Każdej Wsi”, finansowanego z funduszy strukturalnych Unii Europejskiej. W skali kraju przedsięwzięcie realizowano $\mathrm{w}$ czterech województwach: pomorskim, zachodniopomorskim, kujawsko-pomorskim i łódzkim. Współpraca FIO i partnerów regionalnych w ramach projektu zaowocowała utworzeniem w Polsce 65 placówek edukacyjnych - Małych Przedszkoli, w których opiekę znalazło 1350 dzieci. Najwięcej powstało ich na Pomorzu - w województwie pomorskim (19 dla 390 dzieci) i zachodniopomorskim (18 dla 420 dzieci). Warto dodać, iż na terenie dwóch gmin - Cedry Wielkie i Żukowo, Małe Przedszkola rozpoczęły działalność aż w czterech miejscowościach ${ }^{2}$. Jednostki prowadzone są przez stowarzyszenia wiejskie. Przedszkole utworzone w ramach projektu stanowi pierwszy krok do wyrównania szans edukacyjnych dzieci ze wsi i miast, wypracowania modelu edukacji przedszkolnej dostosowanego do potrzeb środowiska wiejskiego, współpracy na płaszczyźnie rodzice-nauczyciele, a także budowania lokalnych koalicji na rzecz edukacji dzieci.

Szkoły podstawowe na wsi tradycyjnie pełnią rolę ośrodków rozwoju wsi, miejsca edukacji, ale i wydarzeń kulturalnych, sportowych czy miejsca spotkań. W sytuacji zaniku innych instytucji kultury i oświaty na wsi (zmniejszająca się

\footnotetext{
${ }^{2} \mathrm{Na}$ terenie gminy Cedry Wielkie Małe Przedszkola funkcjonują w miejscowościach: Wocławy, Trutnowy, Giemlice i Cedry Wielkie, zaś w gminie Żukowo - Chwaszczyno, Niestępowo, Pępowo, Skrzeszewo.
} 
liczba filii bibliotek gminnych, likwidacja tworzonych w PRL klubokawiarni, powolne reaktywowanie ginących w ostatnich 20 latach Kół Gospodyń Wiejskich) ich rola staje się szczególna - stają się jedynymi instytucjami zlokalizowanymi w małych miejscowościach. Od końca lat 90. XX wieku małe wiejskie szkoły podstawowe są zamykane. Na początku miały na to wpływ: skrócenie nauki w szkole podstawowej (ubyły dwa roczniki), a następnie niż demograficzny oraz przekazanie szkół gminom, które podejmują decyzje o kształcie sieci szkół, kierując się głównie względami ekonomicznymi. Z danych GUS wynika, iż na Pomorzu w latach 1998-2013 liczba szkół podstawowych zmalała o $1 / 3$. W przypadku województwa zachodniopomorskiego odnotowano spadek aż o $41,1 \%$, podczas gdy w pomorskim ubyło w tym okresie $33,7 \%$ szkół podstawowych.

Zdaniem E. Tołwińskiej-Królikowskiej (2011) szkoła wiejska zawsze pełniła nieco inną rolę niż szkoła miejska - współpracowała ze środowiskiem, organizowała imprezy lokalne, organizowała zajęcia dodatkowe i imprezy, które w mieście oferują uczniom i ich rodzinom inne placówki. Obecnie ta rola powinna wzrosnąć - szkoła powinna być ośrodkiem rozwoju społeczności lokalnej i edukacji przez całe życie (Life-Long Learning): miejscem spotkań młodzieży, dorosłych i całych rodzin, miejscem edukacji małych dzieci i ich rodziców, edukacji przedszkolnej, szkolnej, zajęć świetlicowych dla młodzieży, edukacji dorosłych - formalnej i nieformalnej, dostępu do źródeł wiedzy i kontaktu z nowymi technologiami (biblioteka, dostęp do komputerów i Internetu). Wiejska szkoła powinna także stanowić miejsce rozrywki i zajęć sportowych (sale gimnastyczne, boisko). Uczynienie ze szkół wielozadaniowych centrów rozwoju lokalnego i edukacji przez całe życie pozwoli na ekonomiczne ich wykorzystanie niezależnie od sytuacji demograficznej - dla małych dzieci, uczniów, młodzieży czy dorosłych. Jednak warunkiem realizacji wizji szkoły jako centrum rozwoju lokalnego jest zaangażowanie całej społeczności wiejskiej. W tym celu powinno się promować i ułatwiać zakładanie lokalnych stowarzyszeń, które mogą realizować różne cele ważne dla społeczności, wspierać szkołę i pozyskiwać dodatkowe środki na jej działania.

Organizacją, która pomaga rodzicom oraz środowiskom lokalnym zakładać stowarzyszenia rozwoju wsi, integrujące mieszkańców, zachęcające wspólnoty sąsiedzkie do samoorganizacji i aktywności, a także przejmowania i prowadzenia małych szkół, przekształcających się w ośrodki edukacji powszechnej całych społeczności, centra kultury, wzajemnej pomocy i rozwoju gospodarczego jest Federacja Inicjatyw Oświatowych (FIO). Była ona realizatorem programu „Mała Szkoła" i jego kontynuatorów. Doświadczenia FIO zebrane podczas przedsięwzięcia w ramach pierwszej edycji potwierdziły, że rodzice chętnie angażują się w działalność placówek edukacyjnych, jeśli otrzymają zachętę i wsparcie. 
Przygotowują pomieszczenia, dbają o placówki, biorą udział w zajęciach i współpracują z władzami lokalnymi ${ }^{3}$.

Utworzone w ramach programu placówki edukacyjne stanowią lokalne centra rozwoju. Stowarzyszenia Rozwoju Wsi prowadzą w nich szkolenia dla dorosłych (m.in. dla rolników, dofinansowywane przez Agencję Restrukturyzacji i Modernizacji Rolnictwa), przedszkola, świetlice, kawiarenki internetowe, zajęcia profilaktyczne i wyrównawcze dla dzieci, młodzieży i dorosłych. Ponadto w budynku szkolnym są organizowane imprezy okolicznościowe integrujące społeczność lokalną. Przejęcie szkoły powoduje, iż zmienia się sposób myślenia mieszkańców wsi. Uczą się oni zarządzania, samodzielności, inicjatywy, wieś rozwija się, aby utrzymać placówkę oświatową, stowarzyszenia podejmują działania gospodarcze, zdobywają na ten cel środki z funduszy Unii Europejskiej. Środowiska wiejskie przyczyniają się w ten sposób do transformacji swoich gmin i regionów, a tym samym kreują wizerunek wsi.

W ramach realizacji programu na Pomorzu utworzono łącznie dziesięć Małych Szkół, w tym siedem na terenie województwa pomorskiego i trzy w województwie zachodniopomorskim (tab. 3). Większość placówek edukacyjnych (7) posiada status niepublicznych. W skali kraju od 1999 roku powstało około 300 Małych Szkół prowadzonych przez organizacje pozarządowe i osoby prywatne.

Tabela 3

Placówki edukacyjne utworzone na Pomorzu w ramach programu „Mała Szkoła”

\begin{tabular}{|c|c|c|c|c|}
\hline Lp. & Województwo & Gmina & $\begin{array}{c}\text { Miejscowość - } \\
\text { lokalizacja placówki }\end{array}$ & \begin{tabular}{|c|} 
Status \\
placówki*
\end{tabular} \\
\hline 1 & \multirow{7}{*}{ Pomorskie } & Skórcz & Barłożno & $\mathrm{n}$ \\
\hline 2 & & Puck & Domatówko & $\mathrm{p}$ \\
\hline 3 & & Linia & Głodnica & $\mathrm{n}$ \\
\hline 4 & & Miastko & Kamnica & $\mathrm{p}$ \\
\hline 5 & & \multirow{2}{*}{ Dębnica Kaszubska } & \multirow{2}{*}{ Niepoględzie } & $\mathrm{n}$ \\
\hline 6 & & & & $\mathrm{n}$ \\
\hline 7 & & Kartuzy & Pomieczyńska Huta & $\mathrm{p}$ \\
\hline 8 & \multirow{3}{*}{ Zachodniopomorskie } & Marianów & Gogolewo & $\mathrm{n}$ \\
\hline 9 & & Rymań & Gorawino & $\mathrm{n}$ \\
\hline 10 & & Bielice & Parsów & $\mathrm{n}$ \\
\hline
\end{tabular}

Objaśnienia: ${ }^{*} \mathrm{p}$ - publiczna, $\mathrm{n}$ - niepubliczna.

Żródło: opracowanie własne na podstawie wykazu Małych Szkół według stanu w 2003 roku, Federacja Inicjatyw Oświatowych.

${ }^{3}$ http://fio.org.pl (dostęp: 30.09.2014). 
W aspekcie rozwoju placówek edukacyjnych dla dzieci warto wspomnieć o ciekawych inicjatywach podejmowanych przez Fundację „Kaszubskie Słoneczniki”. Jednym z celów organizacji jest wspieranie inicjatyw oraz podejmowanie działań służących wszechstronnemu rozwojowi dzieci i młodzieży. Realizuje go m.in. poprzez prowadzenie szkół, przedszkoli i świetlic, organizowanie zajęć pozalekcyjnych i pozaszkolnych, a także imprez kulturalnych i sportowych, szkoleń, warsztatów, konferencji, przyznawanie stypendiów dla dzieci i młodzieży oraz odkrywanie, wspieranie i promowanie osób utalentowanych ${ }^{4}$. Siedzibą fundacji jest miejscowość Gogolewko w gminie Dębnica Kaszubska, nosząca miano Słonecznikowej Wsi - jest to wioska tematyczna utworzona w 2004 roku, jako inicjatywa członków Fundacji Kaszubskie Słoneczniki. Motywem przewodnim wsi jest słonecznik, który symbolizuje optymizm i inspiruje do podejmowania wyzwań. W świetlicy wiejskiej znajduje się niewielkie muzeum z eksponatami, które mieszkańcy wyszukali sami. Wieś ma swoją ścieżkę przyrodniczo-historyczną „Słonecznikowy trakt” oraz swoją coroczną imprezę ,Jarmark Słonecznikowy”.

Fundacja jest realizatorem przedsięwzięcia, mającego na celu stworzenie sieci innowacyjnych małych przedszkoli na Pomorzu. Obecnie prowadzi siedem ośrodków przedszkolnych (3 przedszkola i 4 punkty przedszkolne) oraz dwa żłobki (tab. 4 ). Placówki zlokalizowane są na terenie trzech gmin - Ustka i Kobylnica $\mathrm{w}$ powiecie słupskim oraz Tuchomie $\mathrm{w}$ powiecie bytowskim. W placówkach edukacyjnych wdrażane są autorskie pomysły i edukacyjne projekty europejskie. Należy dodać, iż Fundacja utworzyła na wsiach znacznie więcej przedszkoli, jednakże z powodu braku dofinansowania zostały one zlikwidowane, bądź przejęte przez samorządy gminne, które z powodzeniem prowadzą je nadal. Dotychczas zrealizowano trzy projekty, w ramach których utworzono słonecznikowe przedszkola i żłobki. Pierwszy projekt pn. „Słonecznikowe przedszkola”, wdrażano od 2008 roku, a dwa kolejne od 2013 roku - „Ulica Słonecznikowa” (w partnerstwie z gminą Kobylnica) i „W siedmiomilowych butach"(w partnerstwie z gminą Ustka). Przedsięwzięcia współfinansowano ze środków Unii Europejskiej w ramach Europejskiego Funduszu Społecznego z Programu Operacyjnego Kapitał Ludzki.

$\mathrm{Na}$ Pomorzu, oprócz przedsięwzięć realizowanych na rzecz rozwoju szkół podstawowych i przedszkoli w środowiskach wiejskich, podejmowane są także różnorodne działania skierowane do szkół gimnazjalnych i ponadgimnazjalnych. Przykładem może być projekt Starostwa Powiatowego w Kościerzynie pt. „Edukacja kluczem do sukcesu", zrealizowany w ramach Programu Operacyjnego Kapitał Ludzki, Priorytet IX, Rozwój wykształcenia i kompetencji w regionie, Działanie 9.5. Oddolne inicjatywy edukacyjne na obszarach wiejskich. Projekt

${ }^{4}$ Statut Fundacji ,,Kaszubskie Słoneczniki”, http://www.przedszkola.sloneczniki.org/ uploads/media/statut_fks_jednolity_12.2010.pdf (dostęp: 7.10.2014). 
był zatem współfinansowany przez Unię Europejską w ramach Europejskiego Funduszu Społecznego, a jego zasadniczym celem było podniesienie świadomości mieszkańców obszarów wiejskich powiatu kościerskiego w zakresie korzyści płynących z kształcenia i szkolenia. Ponadto w ramach wspomnianego wyżej działania podejmowanych było szereg przedsięwzięć skierowanych do osób starszych i w średnim wieku. Przykładem może być projekt promujący podnoszenie kwalifikacji na terenie wsi Borkowo i Straszyn pn. „Na naukę nigdy nie jest za późno", którego beneficjentem było Stowarzyszenie mieszkańców Borkowa w gminie Pruszcz Gdański czy też „Edukacja oknem na świat” pod egidą Stowarzyszenia Rozwoju i Promocji Wsi Wysin.

Tabela 4

Placówki edukacyjne Fundacji „Kaszubskie Słoneczniki” na Pomorzu

\begin{tabular}{|c|c|c|c|}
\hline Nazwa projektu & $\begin{array}{c}\text { Rodzaj placówki } \\
\text { edukacyjnej }\end{array}$ & $\begin{array}{c}\text { Miejscowość - } \\
\text { lokalizacja placówki }\end{array}$ & Gmina \\
\hline \multirow{5}{*}{$\begin{array}{l}\text { Słonecznikowe } \\
\text { przedszkola }\end{array}$} & \multirow{2}{*}{ przedszkola } & Ustka & Ustka \\
\hline & & Sycewice & Kobylnica \\
\hline & \multirow{3}{*}{$\begin{array}{c}\text { punkt } \\
\text { przedszkolny }\end{array}$} & Starkowo & Ustka \\
\hline & & Duninowo & Ustka \\
\hline & & Modrzejewo & Tuchomie \\
\hline \multirow{2}{*}{$\begin{array}{l}\text { W siedmiomilo- } \\
\text { wych butach }\end{array}$} & przedszkole & Kobylnica & Kobylnica \\
\hline & $\begin{array}{c}\text { punkt } \\
\text { przedszkolny }\end{array}$ & Charnowo & Ustka \\
\hline \multirow{2}{*}{$\begin{array}{l}\text { Ulica } \\
\text { Słonecznikowa }\end{array}$} & \multirow{2}{*}{ żłobek } & Kobylnica & Kobylnica \\
\hline & & Ustka & Ustka \\
\hline
\end{tabular}

Źródło: opracowanie własne na podstawie materiałów Fundacji „Kaszubskie Słoneczniki”.

Działanie 9.5 Oddolne inicjatywy edukacyjne na obszarach wiejskich w ramach PO KL na Pomorzu pozwoliło na realizację 470 projektów, w tym 211 na terenie województwa pomorskiego i 259-zachodniopomorskiego (rys. 1). Zasadniczym jego celem było obudzenie aktywności mieszkańców obszarów wiejskich na rzecz samoorganizacji i tworzenia lokalnych inicjatyw ukierunkowanych na rozwój edukacji i podnoszenia poziomu wykształcenia mieszkańców obszarów wiejskich. W zakresie edukacji najwięcej zrealizowano ich na wsiach powiatu słupskiego - 48, co stanowiło $22,7 \%$ zrealizowanych projektów w województwie pomorskim. Z kolei w województwie zachodniopomorskim prym wiodły powiaty goleniowski (37 projektów) i policki (32 projekty), a więc odpowiednio $14,3 \%$ i $12,3 \%$ podjętych działań w regionie. A zatem środki unijne w sposób znaczący pomagają w realizacji różnorodnych projektów przyczyniających się do szeroko pojętego rozwoju edukacji na obszarach wiejskich Pomorza. 


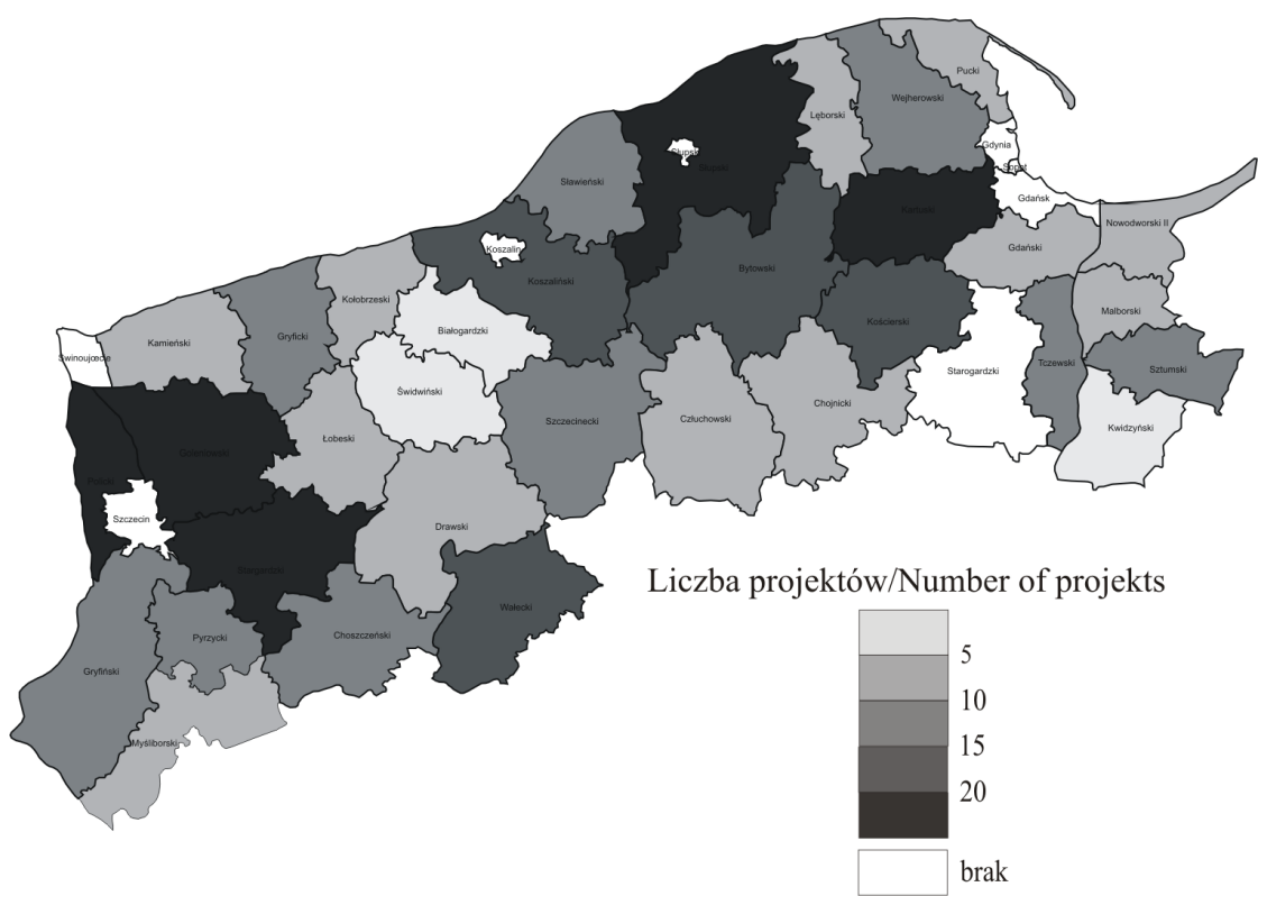

Rys. 1. Projekty zrealizowane na Pomorzu w ramach działania 9.5 Oddolne inicjatywy edukacyjne na obszarach wiejskich finansowanego ze środków Europejskiego Funduszu Społecznego, Program Operacyjny Kapitał Ludzki

Źródło: opracowanie na podstawie www.mapadotacji.gov.pl

Ciekawym przejawem działalności na rzecz rozwoju edukacji była inicjatywa utworzenia w 1999 roku stowarzyszenia „Speranda”, podjęta przez mieszkańców popegeerowskich wsi Niepoględzie i Gałęzowo. Siedzibą organizacji i miejscem działalności jest budynek XIX-wiecznego zabytkowego pałacu w Niepoględziu, będący jego własnością. Stowarzyszenie prowadzi dwie szkoły społeczne - gimnazjum i szkołę podstawową, w których nauka jest bezpłatna, niepubliczne przedszkole oraz świetlicę wiejską. W placówkach naukę pobierają uczniowie z trzynastu popegeerowskich wsi, zlokalizowanych na terenie czterech gmin - Dębnica Kaszubska (powiat słupski), Kołczygłowy, Czarna Dąbrówka, Borzytuchom (powiat bytowski). W szkołach, obok edukacji programowej, prowadzone są dodatkowe zajęcia z języków obcych, informatyki, ekologii oraz sztuki. Ponadto, Stowarzyszenie prowadzi Klub sportowy „Dolina Speranda", w którym działają trzy sekcje - karate, piłki nożnej i jeździecka. W przypadku tej ostatniej, działania Stowarzyszenia zmierzają w kierunku reaktywacji tradycji jeździeckiej w regionie ${ }^{5}$.

\footnotetext{
${ }^{5}$ http://www.niepogledzie.pl (dostęp: 7.10.2014).
} 
W Polsce od kilkunastu lat bardzo prężnie rozwija się nurt Odnowy Wsi, który przybiera różnorodne formy. Jedną z nich jest coraz popularniejsza idea wioski tematycznej, będącej pomysłem na tworzenie miejsc pracy $\mathrm{z}$ wykorzystaniem potencjału, umiejętności i pomysłów ludzi oraz infrastruktury i przestrzeni $\mathrm{w}$ danej miejscowości. Jest sprawdzoną, a zarazem skuteczną metodą aktywizowania obszarów wiejskich i pobudzania ich rozwoju (Czapiewska 2012). Tworzenie wsi tematycznych jest przejawem działań na rzecz rozwoju edukacji w środowisku wiejskim. Poprzez specjalizacje kreują one wizerunek miejscowości. Stanowią kompleksowy projekt, mający na celu ożywienie gospodarki wiejskiej, poprzez integrację lokalnej społeczności wokół zagadnień związanych z jakimś produktem, usługą lub kulturą danego regionu. Pomysły na specjalizacje wsi są oczywiste w miejscowościach o bogatej tradycji. Wykorzystuje się tam dotychczasowe doświadczenia, umiejętności i kontakty, rozwijając na podstawie tradycyjnych zajęć nowe formy działalności. Dziedzictwo oraz tradycje ożywają w formie warsztatów, gier terenowych, zabaw plenerowych, programów edukacyjnych czy produktów lokalnych (Idziak 2003). Wieś tematyczna poszerza horyzonty, inspiruje do nowych pomysłów, do myślenia o tym, jak stworzyć świetlicę, jakiej nie było, co w niej ciekawego, twórczego i pożytecznego można robić, jak ze świetlicy, szkoły czy remizy uczynić ośrodek rozwoju wsi.

Na Pomorzu zlokalizowanych jest łącznie osiem wsi tematycznych, w tym sześć na terenie województwa zachodniopomorskiego i dwie w województwie pomorskim (tab. 5). Województwo zachodniopomorskie jest liderem na skalę krajową $\mathrm{w}$ tworzeniu i funkcjonowaniu wsi tematycznych, a równocześnie wzorem, z którego czerpały inspirację miejscowości z innych województw Polski.

Na Pomorzu funkcjonują szkoły i wsie o ciekawych specjalizacjach. Przykładem może tu być szkoła podstawowa w Sierakowie Sławieńskim, dzięki której rozwija się specjalizacja wsi. Szkoła jest miejscem spotkań stowarzyszenia „Hobbiton”. Wielokrotnie zamieniała się - w schronisko, stołówkę, miejsce wytwarzania różnych sprzętów potrzebnych do organizacji imprez. Specjalizacja miejscowości Sierakowo Sławieńskie opiera się na tematyce związanej z twórczością J.R.R. Tolkiena - „Wioska Hobbitów”. Funkcjonująca tam „szkoła w wiejskiej zagrodzie” daje możliwość czynnego uczestniczenia w zajęciach takich, jak ubijanie masła czy chów zwierząt gospodarskich, przybliżając uczestnikom realia życia na wsi. Innym przykładem jest wieś Podgórki, w której przed transformacją funkcjonowało państwowe gospodarstwo rolne. Po upadku PGR-u, opuszczone budynki, by uchronić przed dewastacją, lokalna społeczność zaadaptowała na pomieszczenia, gdzie prowadzone są zajęcia $\mathrm{w}$ ramach specjalizacji wsi opierającej się na zagadnieniach związanych z bajką i rowerami. Wieś oferuje zajęcia $\mathrm{w}$ pracowniach artystycznych (ceramika, papieroplastyka, malowanie na szkle i folii, wyrób świec z wosku), bajkowe gry i zabawy, 
Tabela 5

Wsie tematyczne na Pomorzu

\begin{tabular}{|c|c|c|c|c|}
\hline Województwo & $\begin{array}{c}\text { Nazwa } \\
\text { wsi } \\
\text { tematycznej }\end{array}$ & Miejscowość & Gmina & Powiat \\
\hline \multirow{2}{*}{ Pomorskie } & $\begin{array}{c}\text { Kraina } \\
\text { Fantazji }\end{array}$ & Karwno & $\begin{array}{c}\text { Czarna } \\
\text { Dąbrówka }\end{array}$ & bytowski \\
\hline & $\begin{array}{c}\text { Słonecznikowa } \\
\text { Wieś }\end{array}$ & Gogolewko & $\begin{array}{c}\text { Dębnica } \\
\text { Kaszubska }\end{array}$ & słupski \\
\hline \multirow{6}{*}{ Zachodniopomorskie } & $\begin{array}{c}\text { Wioska } \\
\text { Hobbitów }\end{array}$ & $\begin{array}{c}\text { Sierakowo } \\
\text { Sławieńskie }\end{array}$ & Sianów & \multirow{3}{*}{ koszaliński } \\
\hline & $\begin{array}{c}\text { Wioska } \\
\text { Zdrowego } \\
\text { Życia }\end{array}$ & Dąbrowa & Sianów & \\
\hline & $\begin{array}{l}\text { Wioska } \\
\text { Końca } \\
\text { Świata }\end{array}$ & Iwięcino & Sianów & \\
\hline & $\begin{array}{c}\text { Wioska } \\
\text { Bajek } \\
\text { i Rowerów }\end{array}$ & Podgórki & Malechowo & \multirow{2}{*}{ sławieński } \\
\hline & $\begin{array}{c}\text { Wioska } \\
\text { Labiryntów } \\
\text { i Źródeł }\end{array}$ & Paproty & Malechowo & \\
\hline & $\begin{array}{l}\text { Wioska } \\
\text { Dobrej } \\
\text { Energii }\end{array}$ & Brzózki & $\begin{array}{c}\text { Nowe } \\
\text { Warpno }\end{array}$ & policki \\
\hline
\end{tabular}

Źródło: opracowanie własne.

kuglarstwo, a także bajkowo-ekologiczną trasę rowerową. Dawne zabudowania folwarczne wykorzystywano jako zaplecze oferty edukacyjno-artystycznej, która powstała w ramach tworzenia wsi tematycznej. W ,Sali na folwarku” prowadzone są warsztaty artystyczne przez mieszkańców wsi i nauczycieli zaangażowanych w projekt. Inspiracją do powstania wsi tematycznej „Wioska Końca Świata" w Iwięcinie był kościół zbudowany przez zakon Cystersów w XIV wieku. Mieszkańcy prowadzą w świątyni zajęcia dotyczące astronomii i czasu, historii świata rolniczego oraz zajęcia artystyczne z wykorzystaniem słomy i siana. Ponadto dostrzegli możliwość innego wykorzystania obiektów porolniczych, powołując do życia opuszczone stodoły i obory, tworząc w nich gospodarstwo edukacyjne specjalizujące się w fizyce i astronomii. Specjalizacja wsi Dąbrowa opiera się z kolei na promocji zdrowego trybu życia, zgodnego z naturą (zielarstwo, aktywność fizyczna). W ramach projektu wioski tematycznej, mieszkańcy wsi przygotowują m.in. zajęcia edukacyjne oraz terapeutyczne, ścieżki zdrowia, piramidę zdrowia itp. We wsi powstały m.in. dwie ścieżki edukacyjne, w ramach których prowadzone są zajęcia $\mathrm{z}$ tradycyjnego wypieku 
chleba, rozpoznawania ziół leczniczych, można odbyć spacer ścieżką przyrodniczą. To zaledwie kilka przykładów, ale podkreślić należy, iż każda wieś tematyczna jest oddolną inicjatywą edukacyjną. Zdaniem W. Idziaka wieś tematyczna różni się od dotychczasowych sposobów specjalizowania się wsi tym, że jej specjalizacja jest dopasowana do gospodarki opartej na wiedzy, emocjach i twórczości oraz powstaje $\mathrm{w}$ oparciu o nowe czynniki rozwoju, najczęściej natury niematerialnej i emocjonalnej. Temat rozwojowy wsi nie jest dziełem przypadku - pracuje się nad nim systematycznie, stosując różnorodne metody generowania pomysłów. Wieś jako organizacja ucząca się powinna być otwarta na nowe idee i ciekawa świata, współpracująca z naukowcami i artystami. Tam, gdzie trudno porwać do działań całą wieś, tworzone są gospodarstwa o różnorodnych profilach, jak np. edukacyjnym, terapeutycznym, artystycznym czy sportowym. Wsie tematyczne edukują zatem zarówno mieszkańców, jak i osoby z zewnątrz.

\section{Podsumowanie}

Edukacja jest ważną inwestycją społeczną, gospodarczą i polityczną. Wykształcenie i kompetencja ludzi stają się najważniejszymi wartościami współczesnej cywilizacji informacyjnej oraz społeczeństw opartych na wiedzy.

Na przykładzie Pomorza (województwa pomorskiego i zachodniopomorskiego) zaprezentowano wybrane działania edukacyjne, podejmowane przez społeczności lokalne. Wykazano ich znaczący wpływ na rozwój pomorskich wsi. Wśród najciekawszych przedsięwzięć realizowanych na obszarach wiejskich Pomorza należy wymienić projekty „Małe Przedszkole w Każdej Wsi”, „Mała Szkoła” oraz działania podejmowane przez Fundację „Kaszubskie Słoneczniki” czy Stowarzyszenie „Speranda”. Na badanym terenie blisko połowa przedszkoli funkcjonuje na obszarach wiejskich. Podejmowane inicjatywy w zakresie edukacji powodują, że tych placówek systematycznie przybywa. Niewątpliwie do ich rozwoju przyczyniają się w znacznej mierze środki finansowe Unii Europejskiej.

Tworzone placówki stają się motorem przemiany społecznej, której najbardziej symbolicznym elementem jest fakt, że szkoła zaczyna być szczególnym miejscem w przestrzeni użytkowanej przez społeczność lokalną - z instytucji, „placówki oświatowej” przekształca się w miejsce spotkań wspólnoty, otwiera się również na jej potrzeby kulturalne i edukacyjne. Niezwykle ważne dla rozwoju edukacji na pomorskiej wsi jest budowa społeczeństwa obywatelskiego w oparciu o zasadę partnerstwa. Przykładem jest szeroko rozumiane partnerstwo szkoły, rodziców oraz gminy czy powiatu. Dzięki temu istnieje nie tylko możliwość regulowania i poprawy funkcjonowania wiejskiej szkoły, przedszkola czy innych instytucji o charakterze edukacyjnym, społecznym, ale możliwość zaistnienia więzi o charakterze lokalnym. 
W. Idziak (2005) podkreśla, iż w nowej gospodarce, opartej na wiedzy, są i będą ważne takie czynniki, jak: twórczość, wyobraźnia, umiejętności społeczne i emocjonalne, umiejętność uczenia się. Niezwykle ważnym elementem współczesnej edukacji jest jej regionalny charakter. W celu rozbudzania aspiracji edukacyjnych dzieci, coraz częściej realizuje się w szkołach programy z zakresu edukacji regionalnej. Na Pomorzu realizowane są one m.in. poprzez naukę języka kaszubskiego oraz poznawanie kultury tej grupy etnicznej. Ważnym zadaniem edukacji regionalnej jest kształtowanie w młodym pokoleniu poczucia przynależności społecznej i terytorialnej, jako podstawy zaangażowania się w funkcjonowanie w środowisku lokalnym i regionalnym. Przykładowo w Szkole Podstawowej w Lipnicy już od 1993 roku prowadzone są zajęcia pozalekcyjne z zakresu edukacji regionalnej.

Kultura i edukacja nadają kierunek ludzkiemu myśleniu i działaniu, inspirują do zdobywania wiedzy i umiejętności niezbędnych człowiekowi do aktywności. Obecnie nie wystarczają już dawne sposoby mobilizowania i aktywizowania ludzi, a należy szukać nowych pomysłów np. zakładając wioski tematyczne. Według F. Mayora (2001), ,klasyczne systemy i formy edukacji nie nadążają za realiami ekonomicznymi i społecznymi". Wieś z niespotykanym motywem przewodnim to doskonały sposób nie tylko na integrację mieszkańców, ale także na biznes. Zatem edukacja na Pomorzu powinna być mocno i bezpośrednio związana z rozwojem wsi.

\section{LITERATURA}

Adamczyk M., Dutkiewicz W. (red.), 2000, Reforma systemu edukacji - wyzwania, szanse, zagrożenia, Wszechnica Świętokrzyska, Kielce.

Czapiewska G., 2012, Wioski tematyczne sposobem na aktywizacje gospodarczq $i$ spoteczna regionu, Studia i Materiały, „Miscellanea Oeconomicae”, 1, UJK, Kielce, s. $109-123$.

Czapiewska G., 2014, Zróżnicowanie funkcjonalne obszarów wiejskich regionu pomorskiego ze szczególnym uwzględnieniem rolnictwa, [w:] Rudnicki R., Kluba M. (red.), Zintegrowany rozwój obszarów wiejskich w świetle polityki Unii Europejskiej, UMK, Toruń, s. 171-185.

Delors J. (red.), 1998, Edukacja - jest w niej ukryty skarb. Raport dla UNESCO Międzynarodowej Komisji do spraw Edukacji dla XXI wieku, Stowarzyszenie Oświatowców Polskich, Wydawnictwo UNESCO, Warszawa.

Idziak M., Rewitalizacja obiektów porolniczych na przykladzie zachodniopomorskich wsi tematycznych, www.wioskitematyczne.org.pl (dostęp: 2.10.2014).

Idziak W., Wieś w gospodarce wiedzy, twórczości $i$ emocji; www.wioskitematyczne. org.pl (dostęp: 3.10.2014).

Idziak W., 2003, Specjalizacja szkół wiejskich i wsi jako forma aktywizacji spoteczności lokalnych, [w:] Kłodziński M., Dzun W. (red.), Aktywizacja wiejskich obszarów problemowych, IRWiR PAN, Warszawa, s. 99-112. 
Idziak W., 2005, Rozwój i edukacja - syjamskie bliźnięta, Tekst wygłoszony na V Europejskim Kongresie Odnowy Wsi w St. Poelten, Austria, 20-21 września 2005 roku.

Idziak W., 2011, Idea wiosek tematycznych, [w:] Miejscowość tematyczna. Pomyst na lokalna aktywność i prace, http://www.eswip.pl/media/file/Publikacje/Miejscowosctematyczna-PNLAiP-2011.pdf_(dostęp: 1.10.2014).

Kierunki rozwoju obszarów wiejskich. Założenia do Strategii zrównoważonego rozwoju wsi i rolnictwa, 2010, MRiRW, Warszawa.

Mayor F., 2001, Przyszłość świata, red. nauk. przekładu W. Rabczuk, Fundacja Studiów i Badań Edukacyjnych, Warszawa.

Okoń W., 2007, Nowy słownik pedagogiczny, Wydawnictwo Akademickie Żak, Warszawa.

Oświata $i$ wychowanie w roku szkolnym 2012/2013, 2013, GUS, Warszawa.

Program rozwoju edukacji na obszarach wiejskich na lata 2008-2013, 2008, MEN, Warszawa.

Siemieniecka B., 2003, Kierunki zmian we wspótczesnej edukacji a technologia informacyjno-komunikacyjna, [w:] Juszczyk S. (red.), Edukacja medialna w społeczeństwie informacyjnym, Torun, s. 25-31.

Statut Fundacji „Kaszubskie Stoneczniki”, http://www.przedszkola.sloneczniki.org/ uploads/media/statut_fks_jednolity_12.2010.pdf (dostęp: 7.10.2014).

Strategia rozwoju edukacji na terenie powiatu nowodworskiego 2012-2020, www. nowydworgdanski.pl (dostęp: 20.11.2014).

Tołwińska-Królikowska E., 2011, Mała wiejska szkoła podstawowa - niezbędny ośrodek rozwoju społeczności lokalnej, Materiał z debaty „Szanse edukacyjne na obszarach wiejskich", Warszawa, 15 czerwca $2011 \mathrm{r}$.

Wilkin J. (red.), 2003, Podstawy strategii zintegrowanego rozwoju rolnictwa i obszarów wiejskich $w$ Polsce, Wydawnictwo Uniwersytetu Warszawskiego, Warszawa.

Wnuk-Lipiński E., Ziókowski M. (red.), 2001, Pierwsza dekada niepodległości. Próba socjologicznej syntezy, Instytut Studiów Politycznych PAN, Warszawa.

\title{
Źródla internetowe
}

http://fio.org.pl.

http://www.niepogledzie.pl.

www.wioskitematyczne.org.pl.

\section{SELECTED INITIATIVES SUPPORTING EDUCATION AND THEIR IMPACT ON SOCIO-ECONOMIC DEVELOPMENT OF POMERANIAN RURAL AREAS}

\begin{abstract}
Education is all activities and processes to transferring knowledge and the shaping specific qualities and skills. In this article on example of Pomerania (Pomeranian and West Pomeranian voivodeships) are presented selected educational activities undertaken by local communities that affect the development of the Pomeranian village and create their image. There is depicted a general state education of research area. Primary and nursery schools dominate among educational institutions in rural areas so there is devoted to them most space in this paper. A kindergarten education became almost as important as the education that children receive in school nowadays. In the countryside kindergartens not only educates but also develop social skills increase
\end{abstract}


educational opportunities support children's individual learning needs and support parents. In Pomerania there are 2044 kindergartens including $45.8 \%$ in rural areas. The activity of selected organizations in the education of children and young people from rural communities was covered mainly by creating small schools and kindergartens, and specialization of the village. There is currently extremely important the acquisition of EU funds for developing a broadly defined rural education.

Projects: „Little Kindergarten in Every Village”, „Little School” and the action taken by the „Kashubian Sunflowers” or the Association „Speranda” can mention among the most interesting projects implemented in the rural areas of Pomerania. Established educational institutions are the local development centers.

Key words: rural areas, education, local community.

Dr Gabriela Czapiewska

Zakład Geografii Społeczno-Ekonomicznej i Turystyki

Instytut Geografii i Studiów Regionalnych

Wydział Matematyczno-Przyrodniczy Akademia Pomorska w Słupsku 